Journal Homepage: http://pusdikra-publishing.com/index.php/jrss

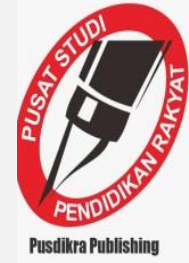

\title{
PERENCANAAN STRATEGIS DALAM UPAYA PENINGKATAN MUTU LULUSAN DI MTs DARUL ILMI PANGKALAN BERANDAN
}

\author{
Anggun Indah Sari Rambe ${ }^{1}$, Pitri Nasution ${ }^{2}$, Diyan Yusri ${ }^{3}$ \\ 1,2,3,STAI Jam'iyah Mahmudiyah
}

\begin{tabular}{|c|c|}
\hline & ABSTRACT \\
\hline & $\begin{array}{l}\text { Tujuan dari penelitian ini sebagai berikut:1) Untuk mendeskripsikan } \\
\text { perencanaan strategis yang di MTs Darul Ilmi Pangkalan Berandan. 2) } \\
\text { Untuk mendeskripsikan mekanisme pelaksanaan perencanaan di sekolah } \\
\text { MTs Darul Ilmi Pangkalan Berandan.3) Untuk mendeskripsikan cara } \\
\text { menyusun perencanaan strategis yang efektif dan optimal di MTs Darul } \\
\text { Ilmi Pangkalan Berandan.4) Untuk mendeskripsikan perencanaan } \\
\text { manajemen strategis tersebut dikaitkan dengan visi misi sekolah MTs } \\
\text { Darul Ilmi Pangkalan Berandan. Metode yang digunakan dalam } \\
\text { penelitian ini adalah deskriptif, dengan pengambilan data, wawancara, } \\
\text { dokumentasi, dan subjek ini adalah kepala madrasah, wakil kepala } \\
\text { madrasah, dan guru bidang studi. Adapun hasil penelitian ini adalah } \\
\text { berdasarkan hasil penelitian yang peneliti temukan di MTs Darul Ilmi } \\
\text { Pangkalan Berandan adalah bagaimana perencanaan strategis yang telah } \\
\text { dilakukan oleh kepala madrasah. Setiap pemimpin jika ingin membuat } \\
\text { suatu program maka ia harus membuat planning(perencanaan). } \\
\text { Penyusunan strategi d sekolah ini dimulai dari mengembangkan } \\
\text { pernyataan visi dan misi, melakukan audit internal dan eksternal, } \\
\text { menetapkan tujuan jangka panjang, menyusun rencana strategis dan } \\
\text { menciptakan mutu lulusan secara efektif dan efesien dengan langkah } \\
\text { strategi mempunyai komponen, langkah- langkah strategi yang pertama } \\
\text { penguatan kepada SDM guru. Mekanisme penerapan rencana strategis } \\
\text { dengan cara membenahi terlebih dahulu guru setelah itu siswanya tahap } \\
\text { berikutnya membenahi strukturnya tahap akhir keberhasilan yang akan } \\
\text { berkelanjutan. Sehingga sekolah ini menjadi sekolah yang terfavoritkan di } \\
\text { Pangkalan Berandan mempunyai jumlah murid yang banyak untuk } \\
\text { masuk di sekolah ini. }\end{array}$ \\
\hline Kata Kunci & Perencanaan Strategi, Mutu, Lulusan \\
\hline
\end{tabular}

\section{PENDAHULUAN}

Pendidikan merupakan sebuah hal yang sangat penting dibahas dan selalu dilakukan upaya perbaikan oleh pemerhati pendidikan untuk mendapatkan hasil yang lebih baik. Pendidikan merupakan pembahasan utama dalam setiap negara yang ada dibelahan penjuru dunia, bahkan ada beberapa negara yang siap dan berani mebgalokasikan belanja negaranya sebanyak $50 \%$ untuk pendidikan.

Dalam Undang-Undang Republik Indonesia No. 20 Tahun 2003 Tentang Sistem Pendidikan Nasional dijelaskan: Pendidikan adalah usaha sadar dan 
terencana untuk mewujudkan suasana belajar dan proses pembelajaran agar peserta didik secara aktif mengembangkan potensi dirinya untuk memiliki kekuatan spiritual, keagamaan, pengendalian diri, kepribadian, kecerdasan, akhlak mulia, serta keterampilan yang diperlukan dirinya, masyarakat, bangsa dan negara (Kompri, 2017).

Pendidikan merupakan bagian yang sangat penting dalam tatanan hidup manusia dan merupakan wahana yang dapat dilakukan oleh manusia itu sendiri untuk membentuk manusia-manusia yang lebih baik dari hari ini. Pendidikan memiliki peran yang sangat penting dalam menciptakan kepribadian manusia, tingkah laku manusia, pola pikir manusia dan kebudayaan yang lebih baik dimasa yang akan datang. Seyogyanya pendidikan harus terus dikembangkan sesuai dengan perubahan serta tantangan zaman. Di samping itu kajian tentang pendidikan di Indonesia juga, kini telah digalakkan demi tujuan yang mulia demi mencerdaskan kehidupan bangsa.

Mutu pendidikan yang diinginkan tidak akan terjadi begitu saja. Mutu yang diinginkan tersebut harus direncanakan. Mutu perlu menjadi sebuah bagian penting dalam strategi dalam sebuah institusi dan untuk meraihnya wajib menggunakan pendekatan yang sistematis dengan menggunakan proses perencanaan yang matang. Perencanaan strategi merupakan salah satu bagian dalam upaya peningkatan mutu (Rohiat, 2010).

Oleh karena itu mutu pendidikan sebagai salah satu pilar pengembangan sumber daya manusia sangat penting maknanya bagi pembangunan nasional. Bahkan dapat dikatakan masa depan bangsa terletak pada keberadaan pendidikan yang berkualitas pada masa kini, pendidikan yang berkualitas hanya akan muncul apabila terdapat lembaga pendidikan yang berkualitas. Karena itu, upaya peningkatan mutu pendidikan merupakan titik strategi dalam upaya untuk menciptakan pendidikan yang berkualitas.

Suatu hal yang amat penting akhir- akhir ini dalam pengelolaan pendidikan khususnya pada tingkat satuan pendidikan, yaitu bagaimana manajemen dilaksanakan secara berkualitas. Berbicara mengenai kualitas (derajat) adalah pembicaraan yang bersifat umum, tetapi mengenai Total Quality Management (TMQ) atau kualitas manajemen secara terpadu dalam pengelolaan pendidikan merupakan hal yang lebih khusus (Arifin \& Permadi, 2010).

Pada dasarnya, manajemen mutu terpadu sebagai sebagai suatu cara untuk meningkatkan performance secara terus menerus pada setiap tingkatan operasi atau proses dalam setiap area fungsional dari suatu organisasi dengan menggunakan semua sumber daya manusia dan modal yang tersedia. 
Manajemen peningkatan mutu pendidikan merupakan suatu metode peningkatan mutu yang bertumpu pada lembaga itu sendiri, mengaplikasikan sekumpulan teknik, berdasarkan pada ketersediaan data kuantitatif dan kualitatif, dan pemberdayaan semua komponen lembaga pendidikan untuk secara berkesinambungan meningkatkan kapasitas dan kemampuan organisasi guna memenuhi kebutuhan peserta didik dan masyarakat. Dalam upaya meningkatkan mutu adalah gambaran dan karakteristik menyeluruh dari bidang atau jasa yang menunjukkan dalam kemampuan memuaskan kebutuhan yang diharapkan atau tersirat. Dalam konteks pendidikan, pengertian mutu mencakup input, proses dan output pendidikan.

Gerak pembangunan nasional atau tantangan dewasa ini telah berada pada suatu era "modern". Era tersebut ditandai dengan kemajuan ilmu pengetahuan dan teknologi begitu pula dalam pemanfaatannya. Hal ini memicu lahirrnya penerapan manajemen strategi terhadap peningkatan mutu pendidikan di lembaga pendidikan yang semakin menuntut untuk keahlian dan kekhususan dalam menanganinya, dan menempatkan era ini sebagai era sumber daya manusia. Untuk itu, meningkatkan kualitas lembaga pendidikan dibutuhkan sumber daya manusia yang memiliki kemampuan yang relevan dengan kebutuhan perencanaan pendidikan.

Penyelenggaraan kegiatan pendidikan harus mampu menjamin kualitas kinerjanya. Dengan demikian, manajemen pendidikan dituntut untuk menjaga konsistensi antara visi, misi, tujuan dan target yang berpedoman pada rencana strategis pendidikan. Dengan penerapan manajemen stategi, pendidikan akan me miliki keputusan yang tepat untuk mencapai rencana yang nantinya bermuara kepada tujuan pendidikan (Tim Dosen UPI, 2011).

Pada hakikatnya perencanaan merupakan suatu rangkaian proses kegiatan menyiapkan keputusan mengenai apa yang diharapkan terjadi seperti (peristiwa, keadaan, suasana), dan sebagainya. Perencanaan bukanlah masalah kira-kira manipulasi atau teoritis tanpa fakta atau data yang kongkrit. Perencanaan pendidikan adalah suatu proses intlektual yang berkesinambungan dalam menganalisis, merumuskan, dan menimbang serta memutuskan dengan keputusan dengan keputusan yang diambil harus mempunyai konsistensi internal yang berhubungan secarasistematis dengan keputusan-keputusan lain.

Pendidikan adalah usaha sadar yang dilakukan orang dewasa (pendidik) dalam menyelenggarakan kegiatan pengembangan diri peserta didik agar menjadi manusia yang paripurna sesuai dengan tujuan yang telah ditentukan sebelumnya. Pendidikan bisa membantu manusia mengangkat harkat martabatnya dibandingkan dengan manusia lainnya yang tidak berpendidikan (Kompri, 2017). 
Yang mana sesuai dengan tujuan pendidikan dalam Undang-undang No.20 Tahun 2003 tentang Sistem Pendidikan Nasional pasal 3, “tujuan pendidikan nasioanl adalah mengembangkan potensi peserta didik agar menjadi manusia yang beriman dan bertaqwa kepada Tuhan Yang Maha Esa, berakhlak mulia, sehat, berilmu, cakap, kretif, mandiri, dan menjadi warganegara yang demokratis serta bertanggung jawab".

Tujuan pendidikan nasional merupakan tujuan yang bersifat paling umum dan merupakan sasaran akhir yang harus dijadikan pedoman oleh setiap usaha pendidikan. Artinya, setiap lemaga dan penyelenggara pendidikan harus dapat membentuk manusia yang sesuai dengan rumusan itu, baik pendidikan yang diselenggarakan oleh lembaga pendidikan formal, informal maupun nonformal.

Dengan pengertian pendidikan dan tujuan pendidikan nasional dapat kita simpulkan bahwa dalam membangun pendidikan yang baik dan efektif bagi bangsa dan negara tersebut. Untuk membangun pendidikan tersebut diperlukan strategi dalam membangun pendidikan. Dimana dalam menyusun strategis untuk membangun pendidikan yang efektif bagi bangsa ini diperlukan perencanaan strategis.

Menurut Handoko perencanaan sebagai pemilihan atau penetapan tujuantujuan organisasi, penentuan strategi, kebijakan, proyek program prosedur, metode, sistem, anggaran, dan standar yang dibutuhkan untuk mencapai tujuan. Perencanaan pendidikan adalah sebuah proses yang sistematis dalam rangka mempersiapkan kegiatan-kegiatan dimasa yang akan datang dalam bidang pendidikan. Dimana persoalan-persoalan yang dibahas dalam perencanaan pendidikan mencakup (1) tujuan: apakah yang akan dicapai oleh perencanaan tersebut; (2) posisi sistem pendidikan: bagaimanakah keadaan sistem pendidikan sekarang; (3) alternative kebijakan dan prioritas untuk mencapai tujuan; (4) strategi penentuan cara yang terbaik untuk mencapai tujuan (Machali \& Kurniadin, 2009).

Sedangkan perencanaan strategis pendidikan adalah proses yang sulit, kompleks, dan butuh partisipasi yang membawa organisasi menuju terotoriasing ia tidk meneyediakan resep yang langsung dapat digunakan untuk sukses; sebaliknya, ia membawa organisasi kedalam suatu perjalanan dan menawarkan kerangka kerja untuk menjawab pertanyaan dan memecahkan masalah.

Menurut Robson, "perencanaan strategis mengarahkan pada tindakantindakan penting yang diambil oleh manajer atau pimpinan untuk melaksanakan secara efektif terhadap sebuah perencanaan dan menekankan mencapai tujuan yang telah direncnakan." 
Dengan tersusun perencanaan strategis dalam membangun serta meningkatkan pendidikan dalam bangsa akan menghasilkan mutu pendidikan itu sendiri. Dimana mutu pendidikan di Indonesia memerlukan perbaikan-perbaikan. Yang mana mutu pendidikan adalah suatu proses yang melibatkan pemusatan pada pencapaian kepuasan harapan pelanggan pendidikan, prbaikan terus menerus, pembagian tanggung jawab dengan para pegawai, dan pengurangan kerjan tersisa dan pengerjaan kembali. Untuk itu semua perencanaan strategis dalam meningkatkan mutu pendidikan tersebut diperlukannya implementasi mutu yang dilakukan melalui implementasi prinsip mutu.

Adapun komponen mutu yang harus ada untuk mendukung pendidikan ialah kepemimpinan yang berorientasi pada mutu, pendidikan dan pelatihan (diklat), struktur pendukung, pengajaran dan perlakuan, pengukuran (evaluasi). Implementasi manajemen mutu didalam persekolah Indonesia saat ini dikenal dengan sitilah manajemen peningkatan mutu berbasis sekolah (Cepi Triyatna, (2009).

MTs Swasta Darul Ilmi Pangkalan Berandan mempunyai reputasi yang bagus di mata masyarakat sekitar sehingga masyarakat mempercayakan pendidikan anak- anaknya disana. Hal ini tidak terlepas dari perencanaan strategis dalam upaya peningkatan mutu lulusan di MTs Darul Ilmi Pangkalan Berandan yang diimplementasikan oleh kepala madrasah, serta jajarannya. Prinsip sekolah yang bemutu adalah sekolah yang melakukan perbaikan secara terus menerus (berkelanjutan) dan sebisa mungkin menghindari sajian pendidikan yang tidak baik. Langkah ini dilakukan secara berkelanjutan sehingga menemukan cara menangani masalah dan membuat reparasi yang diperlukan.

Bedasarkan teori yang telah peneliti paparkan diatas, peneliti merasa tertarik untuk mengadakan penelitian dengan judul " Perencanaan Strategis dalam Upaya Meningkatkan Mutu Lulusan di MTs Darul Ilmi Pangkalan Berandan".

\section{METODE PENELITIAN}

Penelitian yang dilakukan ini adalah penelitian kualitatif. Penelitian kualitatif mencoba mencari deskripsi yang tepat dan cukup dari semua aktivitas, objek, proses, dan manusia. penelitian ini berupaya menggambarkan perencanaan strategis dalam upaya meningkatkan mutu lulusan di MTs Darul Ilmi Pangkalan Berandan.

Desain penelitian yang digunakan untuk mengetahui Perencanaan Strategis Dalam Upaya Meningkatkan Mutu Lulusan di MTs Darul Ilmi adalah Desain penelitian kualitatif. Penelitian kualitatif itu berakar pada latar alamiah 
sebagai kebutuhan mengandalkan manusia sebagai alat penelitian, memanfaatkan metode kualitatif, mengadakan analisis data secara induktif, mengarahkan sasaran penelitiannya pada usaha menemukan teori dari dasar, bersifat deskriptif, lebih mementingkan proses daripada hasil, membatasi studi dengan fokus, memiliki seperangkat kriteria untuk memeriksa keabsahan data, rancangan penelitiannya disepakati oleh kedua belah pihak: peneliti dan subjek penelitian

Teknik pengumpulan data adalah "langkah yang paling utama dalam penelitian, karena tujuan utama dari penelitian adalah mendapatkan data. Tanpa mengetahui teknik pengempulan data, maka peneliti tidak akan mendapatkan data yang memenuhi standar data yang ditetapkan (Sugiyono, 2015)."

Sesuai dengan Desain penelitian kualitatif dan sumber data yang digunakan, maka teknik pengumpulan data yang digunakan adalah studi dokumentasi, observasi dan wawancara. Untuk mengumpulkan data dalam kegiatan penelitian diperlukan cara-cara atau teknik pengumpulan data tertentu, sehingga proses penelitian dapat berjalan lancar.

Dalam pengumpulan data diperlukan data yang dapat dipertanggung jawabkan kebenarannya. Dalam penelitian ini untuk memperoleh data dan informasi yang tepat dan valid, maka penelitian menggunakan beberapa teknik dalam pengumpulan data yaitu observasi, wawancara, dan studi dokumentasi

\section{HASIL DAN PEMBAHASAN}

Berdasarkan hasil temuan penelitian yang telah dilakukan sesuai dengan rumusan masalah yang telah dibuat sebelumnya maka dapat dapat dianalisis bahwa:

1. Penyusunan strategi di sekolah ini dimulai dari mengembangkan pernyataan visi dan misi, melakukan audit internal dan eksternal, menetapkan tujuan jangka panjang, merumuskan, mengevaluasi, dan memilih strategi, implementasi strategi dan dilanjutkan dengan mengukur dan mengevaluasi kinerja sekolah tersebut agar dapat sesuai dengan visi misi yang telah dibuat di sekolah ini.

2 Cara menyusun rencana stategis dalam menciptakan mutu lulusan secara efektif dan efesien dengan langkah strategi mempunyai komponen, langkahlangkah strategi yang pertama penguatan kepada SDM guru, yang kedua kualitas pada anak didik.

3. Mekanisme penerapan rencana strategis dengan cara membenahi terlebih dulu guru setelah itu siswa nya tahap berikutnya membenahi strukturnya tahap akhir kebersihan yang akan berkelanjutan. Sehingga sekolah ini menjadi sekolah yang favorit di Pangkalan Berandan karena mempunyai jumlah murid yang banyak untuk masuk ke sekolah ini. 


\section{Perencanaan Strategis Dalam Meningkatkan Mutu Lulusan MTs Darul Ilmi Pangkalan Berandan.}

Berdasarkan hasil penelitian yang peneliti temukan di MTs Darul Ilmi Pangkalan Berandan adalah bagaimana perencanaan strategis yang telah dilakukan oleh kepala Madrasah. Setiap pemimpin jika ingin membuat suatu program maka ia harus membuat sebuah perencanaan maupun planning. Kepala Madrasah juga harus membuat renstra (rencana strategi) untuk satu tahun, dua tahun sampai kepada jangka panjang. Strategi ini dibuat untuk menjadi bahan penguatan untuk para pendidik salah satunya SDM yangakan dibangun oleh Kepala Madrasah adalah SDM guru nya dibangun sudah mumpuni dan tatanan kepada kualitas siswanya.

Sejalan dengan pernyataan kepala sekolah MTs Darul Ilmi Pangkalan Berandan bahwa Mutu tidak terjadi begitu saja.Ia harus direncanakan. Mutu harus menjadi bagian penting dari strategi intuisi, dan harus didekati secara sistematis dengan menggunakan proses perencanaan strategik. Perencanaan strategi memungkinkan formulasi prioritas-prioritas jangka panjang dan perubahan institusional berdasarkan pertimbangan rasional. Tanpa strategi, sebuah instiusi tidak akan bisa yakin bagaimana mereka bisa memanfaatkan peluang-peluang baru (Sallins, 2005).

Dari penjelasan di atas dapat diketahui bahwa sebuah mutu tidak dapat diperoleh tanpa ada perencanaan.Dengan adanya perencanaan, dapat memungkinkan suatu organisasi mencapai tujuannya. Perencanaan akan membantu sebuah organisasi untuk mengetahui hal-hal yang perlu dilakukan dan dengan cara apa mencapai tujuan.

Menggunakan sebuah pendekatan yang sistematis dalam merencanakan masa depan institusi merupakan hal yang penting. Strategi harus didasarkan pada kelompok-kelompok pelanggan dan harapan-harapan mereka yang bervariasi, selanjutnya adalah dengan mengembangkan kebijakan-kebijakan serta rencanarencana yang dapat mengantarkan isntansi pada pencapaian visi dan misinya.

\section{Mutu Lulusan di MTs Darul Ilmi Pangkalan Berandan}

Berdasarkan hasil penelitian yang peneliti temukan di MTs Darul Ilmi Pangkalan Berandan adalah mengenai tentang mutu lulusan dari MTs Darul Ilmi Pangkalan Berandan, keadaan lulusan dari madrasah ini mempunya lulusan yang berkompeten. Dimana mereka telah diterima diberbagai SMA/ MAS untuk melanjutkan sekolah mereka.

Untuk menunjang mutu lulusan yang disampaikan oleh Kepala Sekolah MTs Darul Ilmi Pangkalan Berandan tersebut maka dibutuhkannya tahapan untuk menciptakan ulusan yang unggul dengan cara berikut: 
a. Kelulusan terhadap peserta didik

Mengutip Peraturan Pemerintah Nomor 19 Tahun 2005, Bab X, Pasal 72 Ayat 1 peserta didik dinyatakan lulus dari stauan pendidikan dasar dan menengah setelah menyelesaikan seluruh program pembelajaran apabila : (Prihatin, 2014)

1) Memperoleh minimal nilai baik pada penilaian akhir untuk seluruh mata pelajaran, kelompok mata pelajaran agama dan akhlak mulia, kelompok pelajaran estetika, dan kelompok pelajaran jasmani, olahraga dan kesehatan.

2) Lulus ujian sekolah/madrasah untuk kelompok mata pelajaran ilmu pengetahuan dan teknologi.

3) Lulus ujian nasional.

Sementara itu menurut Diknas bahwa mutu akademik lulusan merupakan gradasi pencapaian lulusan dalam tes kemampuan akademik, yang dalam hal ini Ujian Nasional (UN). Dalam permendiknas No. 78 Tahun 2008 pasal 2 menyatakan bahwa Ujian Nasional bertujuan menilai pencapaian kompetensi lulusan secara nasional bertujuan menilai pencapaian kompetensi lulusan secara nasional pada mata pelajaran tertentu dalam kelompok mata pelajaran ilmu pengetahuan dan teknologi.

b. Standar kelulusan

Dalam Undang-Undang Sirdiknas Bab V tentang Standart Kompetemsi Lulusan pasal 25 disebutkan:

1. Standar kompetensi lulusan digunakan sebagai pedoman penilaian dalam penentuan kelulusan peserta didik dari satuan pendidik.

2) Standar kompetensi lulusan sebagaimana dimaksud pada ayat (1) meliputi kompetensi untuk seluruh mata pelajaran atau kelompok matra pelajaran dan mata kuliah atau kelompok mata kuliah.

3) Kompetensi lulusan untuk mata pelajaran bahasa menekankan pada kemampuan membaca dan menulis yang sesuai dengan jenjang pendidikan.

4) Kompetensi lulusan sebagaimana dimaksud pada ayat (1) dan (2) mencakup sikap, pengetahuan dan keterampilan.

Dari pasal tersebut diketahui bahwa kompetensi kelulusan harus mencakup sikap (afektif), pengetahuan (kognitif), dan keterampilan (psikomotorik).Standar kompetensi ini harus menjadi acuan pada pemerintah dalam menetapkan standar kelulusan.Namun, terjadinya kontradiktif antara ketetapan dengan pelaksanaan di lapangan.

\section{Manajemen Peningkatan Mutu Lulusan}

Manajemen peningkatan mutu kelulusan merupakan sebuah proses yang melibatkan semua bagian dalam lembaga pendidikan. Semua bagian tersebut 
saling berhubungan dan tidak dapat dipisahkan, bagian tersebut diantaranya adalah siswa, tenaga pendidik/guru, kepala skeolah, serta stakeholder atau masyarakat sebagai pengguna lulusan.Kesemua bagian tersebut harus sinergi untuk menghasilkan kinerja sekolah berupa prestasi siswa yang memuaskan.

\section{Pelaksanaan Perencanan Strategi Dalam Meningkatkan Mutu Lulusan di MTs Darul Ilmi Pangkalan Berandan}

Berdasarkan hasil penelitian yang peneliti temukan di MTs Darul Ilmi Pangkalan Berandan adalah mengenai Pelaksanaan Perencanan Strategi Dalam Meningkatkan Mutu Lulusan di MTs MTs Darul Ilmi Pangkalan Berandan adalah adanya langkah-langkah strategi yang mempunyai komponen.Langkah-langkah strategi yang pertama adanya penguatan kepada SDM guru, yang kedua kualitas pada anak didik.

Dari pemaparan di atas dapat diambil kesimpulan bahwa dalam menerapkan strategi perlu merencanakan perubahan dan menganalisisnya dengan memperhatikan lingkungan internal dan eksternal, baik itu sumberdaya, ekadaan sekarang dan yang akan datang, stakeholder, dan teknologi.

\section{Faktor-faktor Pendukung Perencanaan}

Berdasarkan hasil penelitian yang peneliti temukan di MTs Darul Ilmi Pangkalan Berandan adalah mengenai apa saja yang menjadi faktor pendukung perencanaan di Madrasah Faktor pendukungnya itu tentu ada staf- stafnya yang memang memumpuninya dibidang itu sendiri. Ada pula WKM itu adalah orangorang yang membantu kepala Madrasah untuk mensukseskan rencana strategi tadi kalau itu tidak ada berat juga berjalan, jadi kekompakan itu kita bangun sehingga apa yang kita inginkan agar kita capai.

Selain yang disebutkan WKM MTs Darul Ilmi Pangkalan Berandan dalam menciptakan mutu lulusan yang unggul diperlukan beberapa faktor pendukung lainnya, menurut Mahdi dan Ibrahim mengemukakan bahwa ada lima hal penting yang harus diperhatikan dalam perencanaan. Lima hal itu dapat menjadi faktor pendukung demi keberhasilan sebuah perencanaan.

> Ketelitian dan kejelasan dalam membentuk tujuan'

$>$ Ketepatan waktu dan tujuan yang hendak dicapai

$>$ Keterkaitan antara fase-fase operasional rencana dengan penanggungjawaban operasional, agar mereka mengetahui fase-fase tersebut dengan tujuan yang hendak dicapai dengan tim yang bertanggung jawab terhadap operasionalnya atau dengan mitra kerjanya, kemungkinankemungkinan yang bisa dicapai, dan kesiapan perencanaan melakukan evaluasi secara terus menerus dalam merealisasikan tujuan

> Kemampuan organisatoris penanggungjawab operasional (Saefullah, 2013). 


\section{Faktor Penghambat Perencanaan}

Berdasarkan hasil penelitian yang peneliti temukan di MTs Darul Ilmi Pangkalan Berandan adalah mengenaikendala-kendala yakni SDM guru 40\% generasi tua, generasi di ajang pension, jadi kinerja pendidik tersebut sudah tidak lagi bisa paksakan atau dipacu seperti orang muda.Yang kedua, kendala-kendala keuangan yang terbatas oleh pemerintah Jadi banyak juga keterbatasan mengenai keuangan yang telah dijalankan.

Di dalam prakteknya, banyak hal yang menghambat pelaksanaan suatu rencana sehinga rencana tersebut tidak berjalan secara efektif.

a. Pelaksana rencana kurang memiliki pengetahuan yang menyeluruh dari organisasi dimana rencana itu dilaksanakan. Akibatnya, para pelaku dalam melakukan rencana kurang memperhatikan kegiatan dari bagian lain, dan ini akan mengganggu kegiatan bagian lain

b. Pembuat rencana (planner) yang tidak cakap sehingga menghasilkan perencanaan yang tidak tepat. Untuk itu perencanaan haruslah dibuat oleh orang yang ahlinya

c. Perencanaan yang dibuat tidak berdasarkan pada fakta-fakta dan data yang objektif

d. Perencanaan tidak fleksibel/kaku

e. Kesalahan dalam penempatan pegawai dan kepala bagian yang tidak sesuai dengan kemampuan dan keahlian

f. Tidak adanya koordinasi diantara unit-unit dalam organisasi, karena masingmasing unit menganggap bagiannya lebih penting dari unit lain

g. Pelaksana sering tidak memiliki pengetahuan tentang situasi lingkungan yang mempengaruhi jalannya rencana dengan baik.

h. Pelaksana sering tidak mampu meramalkan situasi yang akan datang, yang akan mempengaruhi jalnnya pelaksanaan

i. Para perencana sering menjumpai kesulitan dalam merencanakan kegiatan yang hanya sekali terjadi atau kejadian yang tidak pernah berulang. Akibatnya banyak kekurangan dalam rencana dan rencana itu sulit dilaksanakan

j. Seseorang sering tidak memiliki dana yang cukup untuk menyusun rencana yang lengkap

k. Para pelaksana sering tidak mau mengambil resiko dalam pelaksanaan rencana, sehingga hanya berjalan setengah-setengah.

1. Para pelaksana sering kurang percaya diri dalam pelaksanaan rencana

m. Ketidakmampuan perencanaan untuk memilih alternatif tertentu dengan alasan takut terjadi kegagalan total apabila hanya ada satu alternatif keputusan dalam rencana. 


\section{Evaluasi Pelaksanaan Perencanaan di MTs Darul Ilmi Pangkalan Berandan}

Dalam pelaksanaan strategi, dari proses perencanaan hingga implementasi melibatkan banyak pihak dari berbagai kalangan dalam organisasi. sehingga, setelah memasuki tahap pelaksanaan atau implementasi, perlu dilakukan pengawasan dan evaluasi dalam setiap prosesnya, agar hal-hal yang telah direncanakan sesuai dan tepat atau tidak. Namun, proses evaluasi tidak serta merta berhenti, hasil evaluasi tersebut harus dijadikan acuan untuk memperbaiki kinerja organisasi terus menerus.

Menurut Rohiat, pelaksanaan evaluasi perencanaan ini dapat dilakukan diakhir tahun pembelajaran dengan melihat hasil evaluasi program jaka pendek pada setiap semester atau catur wulan. Evaluasi jangka menengah ini bertujuan untuk mengetahui seberapa jauh program peningkatan mutu telah mencapai sasaran yang telah ditetapkan sebelumnya. Dengan evaluasi ini akan diketahui kekuatan dan kelemahan program untuk diperbaiki pada tahun berikutnya.

Berdasarkan hasil penelitian yang peneliti temukan di MTs Darul Ilmi Pangkalan Berandan adalah mengenai evaluasi pelaksanan perencanaan di MTs Darul Ilmi Pangkalan Berandan untuk mengetahui ketercapaian dan kesesuaian antara rencana yang telah ditetapkan dengan hasil yang dicapai berdasarkan program dan kegiatan yang telah dilakukan oleh Kepala Madrasah maupun tenaga pendidiknya. Evaluasi juga dilakukan untuk mengetahui kesesuaian hasil nyata dengan yang diharapkan sebagaimana tertulis dalam program pelaksanaan perencanaan yang telah dibuat oleh Kepala Madrasah tersebut.

\section{Solusi Terhadap Hambatan-Hambatan Perencanaan}

Untuk menyelesaikan semua permasalahan dalam pelaksanaan perencanaan strategik dalam menciptakan mutu lulusan yang unggul diperlukan solusi berikut ini:

a. Melibatkan para pegawai, terutama mereka yang terkena pengaruh dalam proses perencanaan.

b. Memberikan banyak informasi kepada para pegawai tentang rencana dan kemungkinan akibat-akibatnya sehingga mereka memahami perlunya serta mendapat manfaat yang diharapkan dan apa yang diperlukan untuk pelaksanaan yang efektif.

c. Mengembangkan suatu pola perencanaan dan penetapan yang efektif, suatu "track recordíi" yang berhasil mendorong kepercayaan kepada para pembuat rencana, serta menjadikan rencana baru tersebut diterima.

Menyadari dampak dari perubahan-perubahan yang diusulkan kepada para anggota organisasi dan memperkecil gangguan yang tidak perlu. 


\section{KESIMPULAN}

Berdasarkan hasil penelitian yang telah dilakukan sesuai dengan rumusan masalah yang telah dibuat sebelumnya maka dapat dapat disimpulkan bahwa:

1. Penyusunan strategi di sekolah ini dimulai dari mengembangkan pernyataan visi dan misi, melakukan audit internal dan eksternal, menetapkan tujuan jangka panjang, merumuskan, mengevaluasi, dan memilih strategi, implementasi strategi dan dilanjutkan dengan mengukur dan mengevaluasi kinerja sekolah tersebut agar dapat sesuai dengan visi misi yang telah dibuat di sekolah ini.

2 Cara menyusun rencana stategis dalam menciptakan mutu lulusan secara efektif dan efesien dengan langkah strategi mempunyai komponen, langkah-langkah strategi yang pertama penguatan kepada SDM guru, yang kedua kualitas pada anak didik.

3. Mekanisme penerapan rencana strategis dengan cara membenahi terlebih dulu guru setelah itu siswa nya tahap berikutnya membenahi strukturnya tahap akhir kebersihan yang akan berkelanjutan. Sehingga sekolah ini menjadi sekolah yang favorit di Pangkalan Berandan karena mempunyai jumlah murid yang banyak untuk masuk ke sekolah ini.

\section{DAFTAR PUSTAKA}

Afrizal, Metode Penelitian Kualitatif, (Jakarta: Rajawali Pers, 2014).

Basrowi dan Suwandi, Memahami Penelitian Kualitatif, (Jakarta: PT Rineka Cipta, 2008).

Dadi Permadi dan Daeng Arifin, Kepemimpinan Transformasional Kepala Sekolah dan Komite Sekolah, Bandung: PT Sarana Panca Karya Nusa, 2010).

Departemen Agama RI, Al-Qur'an dan Terjemahnya Al- Jumanatul 'Ali (Seuntai Mutiara yang Maha Luhur, (Bandung: Cv. Penerbit Jumanatul 'Ali Art (JArt) 2005).

Hardjoesoedarmo Soewarso, Total Quality Management, (Yogyakarta: Andi Offest, 2006).

Ikapi, Himpunan Peraturan dan Perundng-undangan Tentang Guru dan Dosen, (Bandung: Fokusmedia).

Kompri, ManajemenPendidikan: Komponen-komponen Elementer Kemajuan

Sekolah. Yogyakarta: Ar-Ruzz Media, 2016).

Kurniadin, Didin dan Imam machali, Manajemen Pendidikan: Konsep dan Prinsip Pengelolaan Pendidikan, (Yogyakarta: Ar-ruzz Media).

Kuswara, Deni dan Cepi Triyatna, Manajemen Pendidikan, (Bandung: Alfabeta, 2009). 
Masyuri dan Zainuddin, Metodologi Penelitian (Pendekatan Praktis dan Aplikatif), (Bandung: PT Refika Aditama, 2008).

Matin, Dasar-dasar Perencanaan Pendidikan, (Jakarta: PT Rajagrafindo Persada, 2013.

Mulyasa.Manajemen Berbasis Madrasah: Konsep.Strategi, dan Implementasi, (Bandung: Remaja Rosdakarya. 2005).

Musaddad, Thontowi Djauhari, "Ilmu Pengetahuan dalam Pandangan Islam" Pelangi Pendidikan, Januari 2007.

Rohiat, Manajemen Sekolah, (Bandung: PT. Refika Aditama, 2010).

Rosady Ruslan, Metode Penelitian: public relations \& Komunikasi, (Jakarta: PT.Raja Grafindo Persada, 2008).

Sallis, Edward, Manajemen Mutu Terpadu, (Yogyakarta: IRCiSoD, 2011).

Saud, Udin Syaefudin \& Abin Syamsuddin Makmun, Perencanaan Pendidikan Suatu Pendekatan Komprehensif, (Bandung: Remaja Rosdakarya, 2005).

Sitorus, Masganti, Metodologi Penelitian Pendidikan Islam, (Medan: IAIN PRESS, 2011).

Sugiyono, Metode Penelitian Kombinasi (Mixed Methods), (Bandung:Alfabeta, 2015).

Syafaruddin, Manajemen Mutu Terpadu dalam Pendidikan, (Jakarta: PT Grasindo, 2016).

Syafaruddin, Pendidikan Transformasional Social,(Bandung: Ciptapustaka, 2009).

Tim Dosen Administrasi Pendidikan UPI, Manajemen Pendidikan, (Bandung: Alfabeta, 2011).

Udin Syaefudin Saud dan Abin Syamsuddin Makmur, Perencanaan Pendidikan, (Bandung: Remaja Rosdakarya, 2005).

Yusuf Hadi Jaya, Menyusun Strategi Berbuah Kinerja Pendidik Efektif, (Medan: Perdana Publishing, 2013). 